\title{
TRADE LIBERALIZATION, DEINDUSTRIALIZATION, AND INEQUALITY Evidence from Middle-Income Latin American Countries
}

\author{
Juan Ariel Bogliaccini \\ University of North Carolina at Chapel Hill
}

\begin{abstract}
This article explores the relationship among trade liberalization, deindustrialization, and income inequality in the more industrially advanced Latin American countries. It argues that, among the most important liberal reforms implemented during the 1980s and 1990s, trade reform was especially detrimental to equality because it accelerated deindustrialization. The analysis provides evidence to support this mechanism. Therefore, as the liberalization of trade increased, the deindustrialization process produced an increase in inequality. In short, evidence shows how the process of economic integration to the global market, as it took place, produced an increase in inequality through the destruction of formal employment.
\end{abstract}

The import substitution industrialization (ISI) model in Latin America created a dual labor market, deepening inequality, which was severe and greater than in other parts of the globe even before the debt crisis (Bulmer Thomas 1996). ${ }^{1}$ But have the liberalization reforms really launched a new model of economic growth and development that has ameliorated income inequality? Or have these reforms further exacerbated inequality? This article shows how trade liberalization reform played an important role in the destruction of formal employment in industry. Concomitantly, this deindustrialization process produced an increase in the levels of inequality. The analysis is done for the Latin American countries that industrialized under the import substitution industrialization (ISI) model: Argentina, Brazil, Chile, Costa Rica, Mexico, Uruguay, and Venezuela.

Latin America had begun its transition from the ISI model to an open-market model at different paces by the late 1970s. By the 1990s almost every political economy in the region was in the process of integration into the global market. The liberalization period constituted a structural adjustment process undertaken under the strong influence of the so-called Anglo-Saxon neoliberal model, which reflects the neoclassical literature description of a capitalist economy (Williamson 1985).

I am thankful to Evelyne Huber, John D. Stephens, Jonathan Hartlyn, James Stimson, Lars Schoultz, Fernando Filgueira, Merike Blofield, Sarah Brooks, Juan Pablo Luna, Sara Niedzwiecki, Santiago Anria, Jan Rovny, Jon Kropko, Diego Hernández, Federico Rodríguez, Santiago Cardozo, Russell BitherTerry, the late Pablo Alegre, and three anonymous $L A R R$ reviewers for their extremely useful comments on previous versions of this article. I also thank Lars Schoultz, David Schwartz, and Alicia Nin for their extensive editorial suggestions and corrections.

1. By 1980,70 percent of households had income below the national average and the income of the richest 20 percent was estimated as ten times greater than the poorest 20 percent (ECLAC 1993; United Nations Development Program 1995).

Latin American Research Review, Vol. 48, No. 2. @ 2013 by the Latin American Studies Association. 
After the debt crisis, the structural adjustment was articulated and monitored by the main debt creditors: international financial institutions (IFIs) and the United States. Parallel to this process, Latin American countries were also entering the third wave of democratization.

It is precisely the strong role of IFIs in promoting and managing the structural adjustment process between the debt crisis and the Argentinean crisis of 2001 that characterizes this twenty-year period as the so-called neoliberal period. During these years, and similarly to what happened after World War II in Western Europe, the convergence hypothesis about a homogeneous liberal, or liberal-based, route to open-market capitalism first gained adherents. Also as in the Western European experience, this hypothesis came under suspicion as the literature began to identify qualitative differences in the paths different countries followed into the global market (Goldthorpe 1984; Keohane 1984; Appel 2000; Huber 2002; Brune, Garrett, and Kogut 2004; Madrid 2005; Bogliaccini and Filgueira 2012). ${ }^{2}$ In other words, the process of convergence toward open-market capitalism should be analytically distinguished from the particular routes that political economies follow for integrating into the global market.

After the neoliberal period, countries have followed quite different routes, some of them following the liberal path (arguably Chile, Costa Rica, and Mexico); some others returning to some kind of coordinated paths (arguably Brazil and Uruguay); and even others remaining in the process of stabilizing their political systems, still arguing over a route to market integration (arguably Argentina and Venezuela, although Argentina may belong to the second group). The influence of IFIs is much weaker, and development processes are more autonomous in a context of strong growth. However, the period between 1980 and 2000 is characterized by reformers' strong political dependence on IFIs, in terms of both credit and projects.

The proposed analysis is based on the premise that the form in which Latin American countries liberalized their markets since the 1980s was not the only available alternative. The literatures on varieties of capitalism and welfare states show that some variations of the European models of capitalism developed more comprehensive welfare systems and have historically had lower inequality levels (Esping-Andersen 1990; Huber and Stephens 2001; Iversen 2005; Pontusson 2005).

There is little debate about the pari passu increase in trade liberalization and inequality during the twenty years between 1980 and 2000. This article aims to shed light on the contested debate about the causal association between the two phenomena. Figure 1 illustrates the trends in employment in industry as a percentage of total employment during the 1980s and 1990s. During the 1990s, the deindustrialization process is evident in every country. The figure also shows the debt-crisis effect in the evolution of employment in industry and how there was a return to the mean effect after the crisis. Figure 2 illustrates the trends in

2. Schneider and Soskice (2009) propose that Latin American political economies developed a unique post-opening model of capitalism (the so-called hierarchical model) characterized by the clash of patrimonialism, liberalism, and the ISI institutions. Therefore, the convergence hypothesis core is not about a liberal model necessarily but about a unique model after the neoliberal period. 


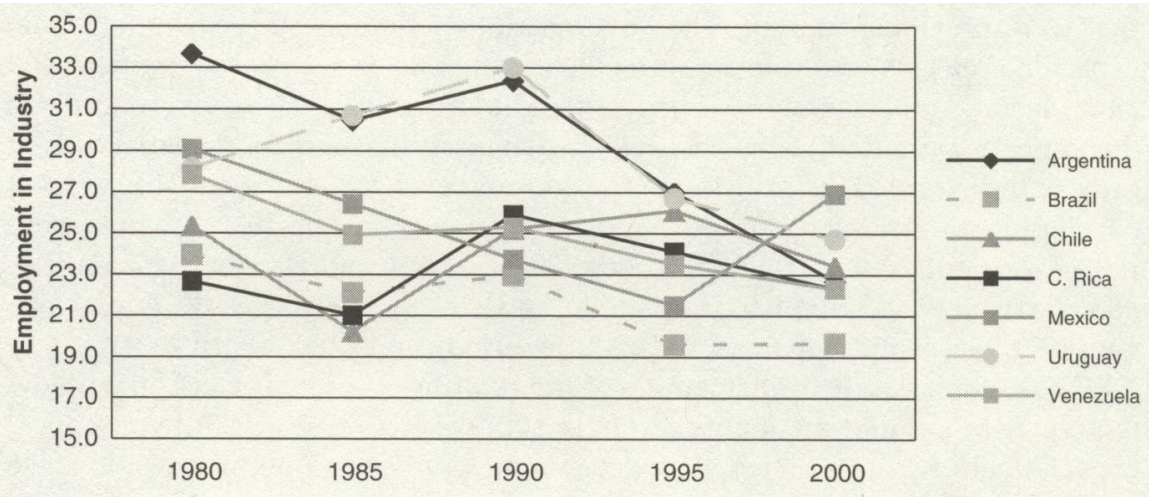

Figure 1 Employment in industry as a percentage of total employment: Average and standard deviation for selected countries, 1980-2000.

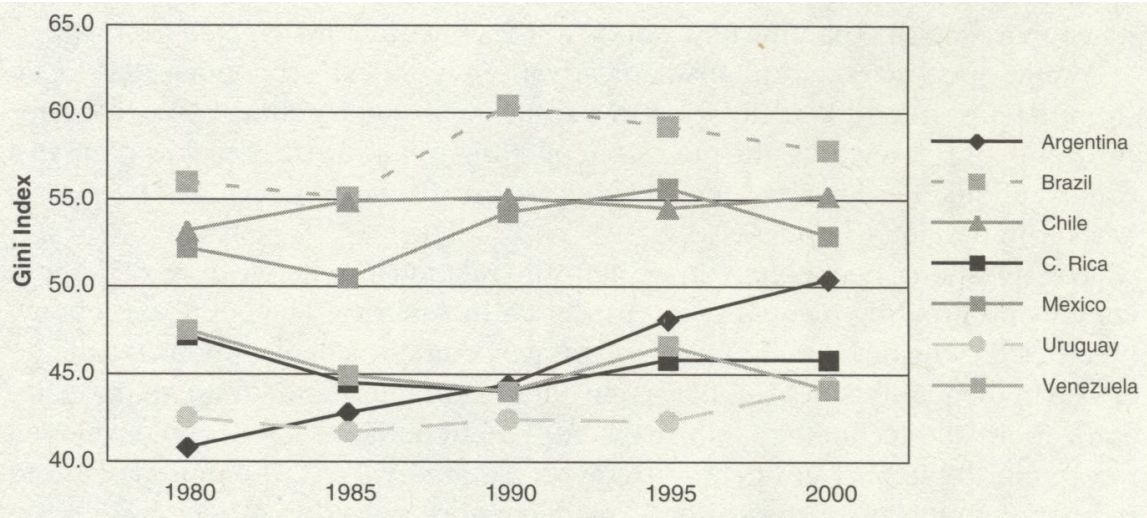

Figure 2 Gini index: Average and standard deviation for selected countries, 1980-2000.

inequality for the same period, measured by the Gini index. Gini is a slow-moving variable; however, its level increased in all countries in the sample but Brazil. In Brazil, where deindustrialization was the least severe in the region, it remained steady (World Bank 2011; Brady, Kaya, and Gereffi 2011).

The availability of new and improved data on income inequality (World Institute for Development Economics Research 2008) allows the use of time series to tackle two puzzles. First is the effect of trade reform on formal industrial employment. Second is the effect of formal employment shrinkage on inequality as trade reform advanced.

\section{TRADE REFORM, DEINDUSTRIALIZATION, AND INEQUALITY}

The cornerstone of the neoliberal model that IFIs proposed for these Latin American countries was the liberalization of trade to promote exportable goods 


\section{Latin American Research Review}

that were previously absent. The advocates of this model argued initially that export-led reforms would foster immediate economic growth based on increased labor demand and capital use (Bhagwati and Martin 1980). ${ }^{3}$ However, contrary to theoretical expectations, empirical evidence suggests that demand for labor did not grow at the expected rates during the period, and even fostered inequality in most developing countries long after the implementation of the reforms, with the exception of the South Asian "tigers" (Woods 1997; Feenstra and Hanson 1997; Hanson and Harrison 1999; Spilimbergo, Londoño, and Székely 1999; Beyer, Rojas, and Vergara 1999; Marjit and Acharyya 2003; Marjit, Beladi, and Chakrabarti 2004).

These empirical disconfirmations of the reforms' expected effect on employment generation and inequality strongly support Kuznets's (1955) hypothetical expectations. Kuznets stated that developing political economies would have scarce opportunities to curve inequality in a way similar to that of the advanced industrial democracies. The argument is grounded on the inability of countries with weak political institutions to control the factors that produce inequality, as, according to Kuznets, income sources of lower social groups were destroyed much more rapidly than the new opportunities the economy created for them.

While open-market capitalism in advanced political economies developed from the post-World War II period in a scenario of stable political and economic institutional frameworks, the process of opening in Latin America was done in a context of much weaker and unstable political institutions, which had been even weaker in previous decades.

The question, then, is how to explain the relationship between trade liberalization and growing inequality in post-ISI Latin America. The political economy literature for the developing world offers two competing explanations for the increase in inequality since the 1980s: the opening of international trade (trade liberalization) and technology improvement. Two hypotheses have been developed to explain the impact of opening trade on inequality. First, the more advanced industrial countries in the region extended trade protection (under ISI) preferentially to industries that made relatively intensive use of unskilled labor (Aedo and Lagos 1984; Hanson and Harrison 1999). Second, the region's liberalization process coincided with the entry of China and other low-skilled-labor countries into the world market, thus shifting the comparative advantage of middle-income countries into goods of middle-skill intensity (Hanson and Harrison 1999). These two processes contributed to the destruction of formal employment for unskilled

3. The rationale for this is the Heckscher-Ohlin (H-O) and Stopler-Samuelson (S-S) models. For a complete discussion and critique of these models, see Marjit and Acharyya (2003). In a nutshell, $\mathrm{H}-\mathrm{O}$ asserts that countries should export goods that use intensively those factors of production that are relatively abundant at home, and import goods that use intensively those factors that are relatively scarce. $S-S$ states that a reduction on trade barriers expands trade by increasing the demand for abundant factors because of the expansion of export sectors, and by reducing the demand for scarce factors because of the concentration of import-competing sectors, with corresponding effects on factor prices. In developing countries, where unskilled labor is abundant and skilled labor is scarce, international trade was expected to raise unskilled wages and to lower skilled wages, narrowing the gap between them (Woods 1997). However, both models have come under increasing criticism because of the assumption of perfectly competitive markets, perfect mobility of factors across sectors of the economy, constant returns to scale technologies, and the absence of nontraded goods, among others (Marjit and Acharyya 2003). 
formal workers. As for the effect of technology improvement on inequality, the main hypothesis states that technological progress in developing countries between the 1960s and the 1980s was biased against unskilled labor (Feenstra and Hanson 1997), thus slowing down the demand for labor, even for those industrial sectors that were already successfully competing in the global market.

The argument exposed in this article goes as follows: inequality levels have grown since the 1980s because income sources of lower social groups were destroyed much more rapidly than new opportunities in terms of the labor market that was created for those groups. ${ }^{4}$ In the more industrially advanced Latin American countries, formal industrial employment was dismantled, and no alternative sources of formal employment (or new safety nets) were put in place. The explanation put forward in this study identifies trade liberalization as a key factor responsible for the shrinking of formal industrial employment. Import competition, particularly where liberalization happened quickly, caused the bankruptcy of many industrial enterprises. Many of them simply closed down, and those jobs were lost. The destruction of formal-sector jobs reduced the income of former workers who were pushed into survival strategies in the informal sector.

At the onset of the liberalization period, the production systems of the set of countries analyzed here were based on the ISI model, and their welfare structures emulated the continental European conservative one, although with different levels of coverage and stratification (Bulmer Thomas 1996; Huber 1996; Filgueira and Filgueira 2002; Filgueira and Bogliaccini 2004). Table 1 shows the main social, political, and economic characteristics of these countries before 1980, acknowledging the high level of variation in terms of social welfare spending, democratic strength, and relative development. However, in all cases there is a relative development of industry as part of the productive structure-even Costa Rica had closed the gap and already belonged to the more advanced industrial countries before liberalization began.

Deindustrialization processes occurred in most high- and middle-income Western political economies between the 1970s and 2000s, but it was particularly intense in middle-income Latin American ones (Iversen 2005; Brady, Kaya, and Gereffi 2011). The trade reform consisted primarily of the reduction of tariffs and other barriers to international trade, such as import quotas. Chile, Argentina, and Uruguay were the first movers in the early 1970s in the context of their bureaucratic authoritarian regimes. On average, tariffs were cut by half over the 1970s, and again from an average of 46 percent in 1990 to 12 percent in 1995 (Morley 2001). Destruction of formal industrial employment was a consequence of the opening of trade and the lack of competitiveness in the domestic industrial sector, which prompted an increase in the size of the informal sector (Portes and Hoffman 2003; Portes and Roberts 2005; ILO 2010). The percentage of the economically

4. This argument is in line with classic works on social consequences of abrupt economic changes, such as Kuznets's (1955) previously cited work and Polanyi's (1944, 167-168) suggested explanation of the Indian famines during the mid-nineteenth century: "The three or four large famines that decimated India under British rule since the Rebellion were thus neither a consequence of the elements, nor of exploitation, but simply of the new market organization of labor and land which broke up the old village without actually resolving its problems." 


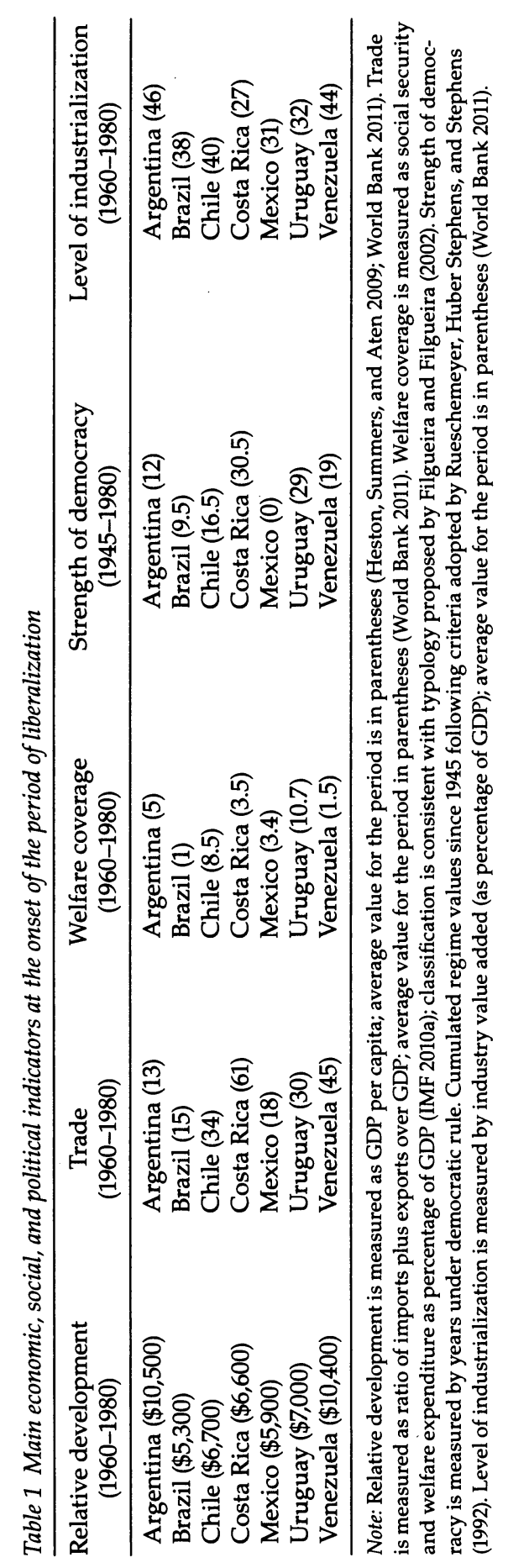


active population working in the informal sector in the seven countries analyzed here rose, on average, from 33 percent in 1980 to 49 percent in 1997 (ILO 1998), whereas employment in industry dropped from an average of 27 percent in 1980 to 22 percent in 2000 for the countries (World Bank 2007).

In other words, the theoretical claim behind the liberal model, that manufacturing exports would trigger industrial employment in developing countries as the abundance of low-skilled labor created a comparative advantage, did not hold in Latin America. As liberalization of trade increased, a process of destroying formal employment also increased because of the inability of domestic industry to compete globally (Brady, Kaya, and Gereffi 2011).

The literature on the effect of liberal reforms on deindustrialization in developing countries also postulates that the destruction of formal employment was more severe in those countries where trade liberalization reformers were backed by the most stable and durable regimes, mostly authoritarian ones. In those cases, the process of dismantling the ISI model and establishing neoliberalism was sustained, unopposed, for a longer time (Gatica 1989; Harvey 2005; Portes and Roberts 2005). In other words, as Brady, Kaya, and Gereffi (2011) state, declining industrial employment may result because more politically insulated, durable states have more time to dismantle the protections for domestic industry.

This process of deindustrialization, in turn, tends to produce an increase in inequality by destroying protected employment and enlarging the informal sector of the economy. Concomitantly, as most welfare states in the region (where they existed) were built on a conservative model of modernization that incorporated urban labor from above and on a contributory basis, and linked to participation in the formal sector of the economy (Esping-Andersen 1990; Collier and Collier 1991; Huber and Stephens 2001; Filgueira and Filgueira 2002), the destruction of the unskilled industrial formal sector weakened the access of middle and lower social sectors to welfare protection.

In summary, opening to the global market did not create opportunities either for specialization in the industrialization of abundant factors, or for technologyintensive production sectors to develop in ex-ISI political economies. Formal employment thus shrank in unopposed authoritarian regimes, or at least in recently democratized regimes with weak civil societies. The informal sector and inequality grew. Welfare systems were not able to provide adequate safety nets to protect against the new risks.

\section{MODELS AND DATA}

The proposed analysis of the relationship among reforms to liberalize trade, deindustrialization, and inequality develops in two stages. To empirically test the causal links proposed earlier, the first stage tests the relationship between trade liberalization and employment in industry. The second stage tests the relationship between employment in industry and inequality. For this second model, an interaction term is included between trade reform and employment in industry to capture how deindustrialization has the effect of increasing inequality as trade reform advances. The analysis is done with yearly data for Argentina, Brazil, 


\section{Latin American Research Review}

Chile, Costa Rica, Mexico, Uruguay, and Venezuela for the period between 1980 and 2000. There are no internal gaps in the panels. ${ }^{5}$

\section{Dependent Variables}

Models 1-3 (table 2) assess the relationship between trade reform and employment in industry as a percentage of gross domestic product (GDP). The measure of employment in industry as a percentage of GDP is the standard measure used in the literature (World Bank 2011). Models 4-6 (table 3) assess the relationship between employment in industry and inequality as the trade reform advances. The measure of income inequality is the standardized Gini index from the World Income Inequality Database (SWIID) (World Institute for Development Economics Research 2008). ${ }^{6}$

\section{Independent Variables for Stage 1}

The measure for trade liberalization reform is the index created by Morley, Machado, and Pettinato (1998). As put forward in the theoretical section, trade liberalization is expected to produce a destruction of employment in industry during the period. ${ }^{7}$

The model also includes a set of control variables that the literature has found to be significant in explaining deindustrialization. The capital account liberalization reform is measured by Chinn and Ito's (2008) index. ${ }^{8}$ This reform was intended to eliminate or reduce restrictions on current account transactions and on capital account transactions, as well as the requirement to surrender hard currency from export proceeds (Morley 2001). Argentina, Costa Rica, and Venezuela already had

5. Missing data for the independent variables were imputed using James Honaker and Gary King's (2007) multiple imputation strategy. The authors developed applications of modern methods for analyzing data with missing values, based primarily on multiple imputations for cross-sectional, time-series, and time-series cross-sectional data. Multiple imputations for missing data had long been recognized as theoretically appropriate.

6. Using standardized Gini data has two main advantages. First, it allows comparison with other countries in Latin America as well as with other parts of the world. Second, it provides a series without gaps, which is necessary to run an error correction model. Refer to Solt (2009) for a detailed explanation of the standardization methodology.

7. As the original indexes were created for the period 1970-1995, I use the indexes as updated until 2000 by Escaith and Paunovic (2004).

8. Morley, Machado, and Pettinato (1998) also have a financial openness index for the analyzed period and also use the IMF Annual Report on Exchange Arrangements and Exchange Restrictions (AREAER, available at http://www.imfareaer.org) as the main source for the index's four indicators: presence of multiple exchange rates, restrictions on current account transactions, restrictions on capital account transactions, and requirement of the surrender of export proceeds. However, Morley, Machado, and Pettinato (1998) also use World Bank memoranda as a source of data. In both cases, the construction of the indexes implies a fundamentally subjective translation of verbal descriptions of controls into numerical indexes. I use Chinn and Ito's (2008) index for two reasons. First, given the interpretation subjectivity problem, I assume that using only one source reduces the validity problem by leaving constant over the period and countries the original (exogenous to the index) conceptualization of the indicators. Second, as Chinn and Ito built the index for 181 countries and for the period 1970-2007, using this index allows for future cross-region comparison and for extension of the analyzed time period. 
relatively open capital markets in the 1970s; Mexico and Uruguay began to open their markets in that decade; and Chile and Brazil maintained significant controls over foreign capital transactions during the entire period (Morley 2001; Chinn and Ito 2007).

GDP per capita (Heston, Summers, and Aten 2009) is included as a measure for overall economic development.9 Trade as a percentage of GDP (World Bank 2011 ) is included as a measure of economic openness. The rationale for including this variable in the model is that the effect of trade reform in employment in industry should be controlled by the level of actual trade in the economy. To control for the impact of foreign direct investment (FDI) in the host economy, the model includes FDI stock as a percentage of GDP (UN Conference on Trade and Development 2009). Inflation is measured as the percentage change in consumer prices (IMF 2010). ${ }^{10}$ Sector dualism, measured as the net difference between employment in agriculture as a percentage of total employment (World Bank 2011) and value added in agriculture (World Bank 2007), refers to the coexistence of a lowproductivity traditional sector and a high-productivity modern sector. Urbanization is the percentage of the population living in urban areas (World Bank 2011).

To control the ability of domestic opposition to oppose the reform, the models include the variable unopposed regimes. This variable is coded as 0 if opposition was allowed in a democratic environment, 0.5 if limited opposition was allowed, and 1 if no opposition was allowed. The rationale for this variable is to assess the relevance of internal opposition for the reforms at the moment the reforms occurred. Bureaucratic authoritarian regimes were coded 0 , and Mexico was coded 0 until 1988 and 0.5 between 1988 and 2000. The coding was done following DíazCayeros and Magaloni's (2001) accepted criteria for defining the Mexican democratization process. Brazil was coded 0.5 between 1985 and 1989, given that elections were not totally free and a military tutelage of the transition process was in place, and Chile was coded 0.5 between 1990 and 2001 for the same reasons and until the position of institutional senator was eliminated. I expect industrial employment to be destroyed in higher proportion in unopposed regimes given an unopposed trade liberalization process.

Finally, the model includes two dummy variables to account for membership in Mercosur and participation in NAFTA, and another dummy variable to account for the periods in which the countries were participating in International Monetary Fund (IMF) loan programs. For Mercosur membership, only full members were considered.

\section{Independent Variables for Stage 2}

Model 6 (table 3) includes an interaction term between trade liberalization reform and employment in industry as a percentage of total employment. The

9. This is a measure of real GDP per capita in constant dollars using the Chain index based on purchasing-power parity (PPP) in 2005 international prices. Therefore, the growth rate for any period is based on international prices most closely allied with the period.

10. Data from the Inter-American Development Bank are used to fill in missing observations for Brazil for the 1970 s and 1980 s. 
theoretical reason for this is the expectation that the effect of the level of employment in industry on inequality would not remain constant as trade reform advances. I expect the destruction of employment in industry to be detrimental to inequality, and its effect to increase as trade liberalization increases.

Among the control variables included in models 4 to 6 , some were also included in the first stage's models: trade and capital account liberalization reforms, trade openness, FDI stocks, inflation, and sector dualism. The advancement of the trade liberalization reform is expected to produce an increase in inequality, as Morley (2001) has found. The hypothesized relationship between the liberalization of the capital account and inequality goes as follows: on the one hand, greater capital openness gives more leverage to capital to press for legislation that favors its interests over those of labor. On the other hand, greater capital openness should increase competition among capital and make capital cheaper, which could work in the other direction.

An increment of GDP per capita should trigger an increase in inequality, as Kuznets (1955) has suggested. Trade as a percentage of GDP (World Bank 2011) is included to control the direct impact of levels of trade flows on inequality. Openness of the economy to trade should theoretically favor the abundant factor of production-unskilled labor-in developing countries. However, since the market opening in Latin America happened around the same time as in countries with even lower labor costs, such as China and countries of Eastern Europe, this effect may be neutralized.

The literature recognizes two main advantages in FDI for the host economy: transferring technology and generating employment. It also recognizes two main disadvantages: repatriation of benefits and a race-to-the-bottom concern about competition for FDI with lower taxes and environment and labor protection standards (Drezner 2001; Mosley and Uno 2007). ${ }^{11}$ A positive relationship between FDI stock and inequality is expected, because investment in industry tended to replace labor with technology, and because investment in unskilled services tended to destroy small and family-owned enterprises.

Accelerated inflation and hyperinflation distort relative prices, whereas chronic inflation undermines prices. This distortion has greater effects on low-income segments of the population. However, hyperinflation was curved in the early 1990s, parallel to the destruction of industrial employment. Sector dualism is expected to contribute to an increase in the overall inequality level of a society (Alderson and Nielsen 1999, 610).

The models also include other controls. The size of the informal sector, measured as the ratio of the labor force in the informal sector of the economy to the total labor force (ECLAC 2010; ILO 2010), is a proxy of the level of formalization of the economy. Given that there is a positive correlation between formal and stable jobs, as well as the fact that the bulk of the welfare and social security spending in the analyzed countries was done on a contributory basis during the period, I expect inequality to increase as the size of the informal sector increases.

11. This point has been argued largely by dependency theorists (Prebisch 1952; Cardoso and Faletto 1979). 
Health and education expenditure, measured as a percentage of GDP, includes subnational expenditure (ECLAC 2010). Spending on health and education increased on average during the liberalization period (Wibbels 2006; Segura-Ubiergo 2007) and was more pro-cyclical than social security spending. This variable is relevant as a measure of human capital formation, but the distributive effect of health and education expenditure depends on its allocation.

Social security and welfare expenditure is measured as a percentage of GDP on a year-to-year basis (IMF 2010). ${ }^{12}$ As most of this expenditure is done on a contributory basis and formal employment is being destroyed, I expect inequality to increase as social security and welfare expenditure remain stagnant or decrease.

To test the hypothesis that increases in inequality were greater where democratic institutions were weaker, the model includes a cumulative measure of democracy as a measure of domestic regime type. ${ }^{13}$ Democracy allows the underprivileged to organize in social movements, it allows parties representing their interests to establish themselves, it allows those parties to elect representatives to the legislatures at all levels, and it allows legislators to have an influence on policy over the long term. For instance, parties can demand compensatory measures for workers affected by job losses and their families. Thus, I expect inequality to increase less in countries with stronger democratic institutions.

Finally, the model also includes the IMF dummy variable to account for the effect of being under an IMF plan on the ability of governments to contain inequality via social expenditure.

\section{Models}

The analysis proceeds with two error correction models (ECMs) with ordinaryleast-squares panel-corrected standard errors. ${ }^{14}$ The error correction model is well suited for the analysis because it allows for estimation of changes in employment in industry and inequality. Based on the assumption that the dependent and independent variables are in a long-term equilibrium relationship, these models allow for the assessment of long-term effects on the dependent variable (De Boef and Keele 2008). The estimated models are of the following form:

$\Delta \mathrm{Y}_{\mathrm{it}}=\beta_{0}+\mathrm{Y}_{\mathrm{t}-1} \phi+\beta_{\mathrm{k}} \Delta \chi_{\mathrm{it}-1}+\chi_{\mathrm{it}-1} \beta_{\mathrm{j}}+\mathrm{D}_{\mathrm{t}}+\mathrm{e}_{\mathrm{it}}$

The dependent variable is measured as first difference, and the right side of the equation includes a lagged dependent variable, as well as both the lagged level

12. This measure, a ratio of spending to GDP (both in current local units), was previously used by Kaufman and Segura (2001) and Huber and colleagues (2006).

13. The variable accumulates regime values since 1945 , codifying them as follows (Rueschemeyer, Huber Stephens, and Stephens 1992): authoritarian regime $=0$, restricted democracy $=0.5$, and full democracy $=1$.

14. Estimation is made with an error correction model that is robust to unit roots. A Fisher test (table A1) validates the suitability of such model, which is estimated using ordinary least squares with panel-corrected errors, as suggested by Beck and Katz $(1995,1996)$, given its relative simplicity and the ease of interpreting results. Error correction models have been used by Kaufman and Segura-Ubiergo (2001) and Segura-Ubiergo (2007), among others, for the study of social-spending determinants in Latin America. 


\section{Latin American Research Review}

and yearly changes of each variable. All variables included in the two models are standardized. The coefficients $\beta_{j}$ measure long-term effects, allowing for assessment of whether trends in independent variables are causally related to long-term trends in the dependent variable. The coefficients $\beta_{\mathrm{k}}$ measure short-term dynamics of the variables, which are influenced by deviation from equilibrium (Enders 2004; De Boef and Keele 2008). The term $D_{t}$ refers to dummies when present in the model. Tables 2 and 3 display the results of the model. The long-run multipliers in these tables are the long-term effect of the variables on the dependent variable. ${ }^{15}$

Variance inflation factor (VIF) tests are performed for the models (table A2 in the appendix), showing that there are no multicollinearity problems. The Breusch-Pagan-Cook-Weisberg test is also performed to rule out the possibility of heteroskedastic standard errors (table $\mathrm{A} 3$ in the appendix). There are no influential data points in the sample for either of the models, as shown in figures A1 and $\mathrm{A} 2$ in the appendix. ${ }^{16}$ Results from $F$-tests reveal that neither country nor year dummies belong to stage 1 models. However, country dummies belong to stage 2 models and are included (not shown in table 3 ).

\section{RESULTS}

Results suggest two broad conclusions: the trade liberalization reform produced a significant destruction of employment in industry, and the destruction of employment in industry produced an increase in income inequality. The analysis of results is done for models 3 and 6 , which are the complete models.

\section{Trade Liberalization and Employment in Industry}

Model 3 shows that the destruction of formal employment in the industrial sector is significantly associated with trade reform over the long run. As trade liberalization advanced, formal employment in industry shrank. The long-term effect of trade liberalization on employment in industry is statistically significant $(p \leq .1)$. Increases in trade liberalization will cause deviations from these two variables' equilibrium, thus causing employment in industry to be too high. In the short term, though not statistically significant, employment in industry increases 0.101 points per each unit increase of trade reform. Therefore, the former will respond in the long run by decreasing by a total of 0.801 points, spread over future time periods at a rate of 12 percent per time period. Figure 3 shows the long-term effect of trade reform on employment in industry.

Consistent with these findings, the Mercosur membership dummy is statisti-

15. Long-term multipliers are obtained by dividing the regression coefficient by the lagged dependent variable $\left(\beta_{\mathrm{j}} /-\phi\right)$. The parameter $U$ measures this long-term equilibrium relationship. Standard errors are calculated for these long-term multipliers, as suggested by De Boef and Keele $(2008,192)$.

16. The scaled difference between the predicted responses from the model constructed from all the data and the predicted responses from the model constructed by setting the $i$-th observation aside (DFITS) was calculated (Welsch and Kuh 1977). 


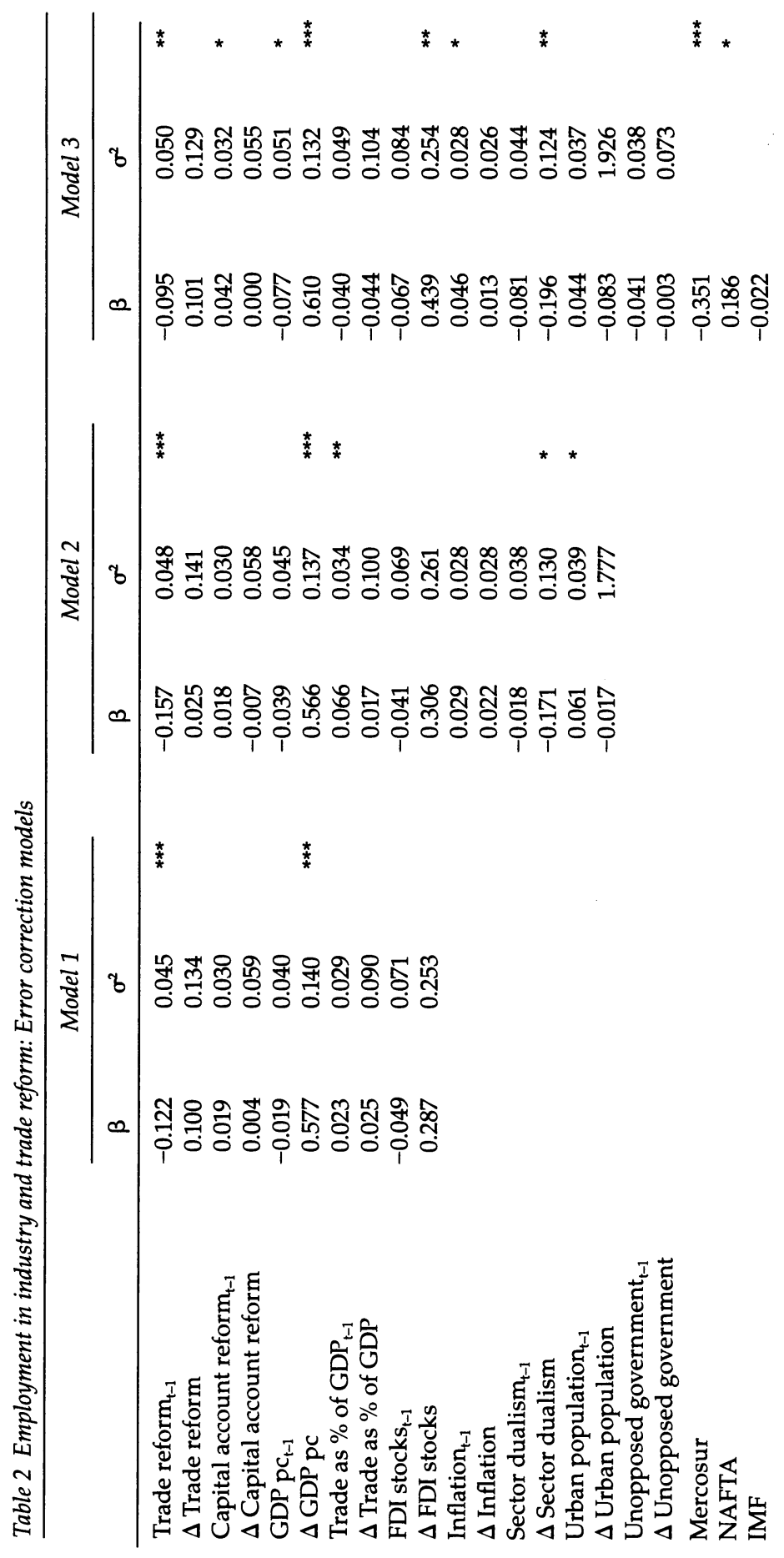




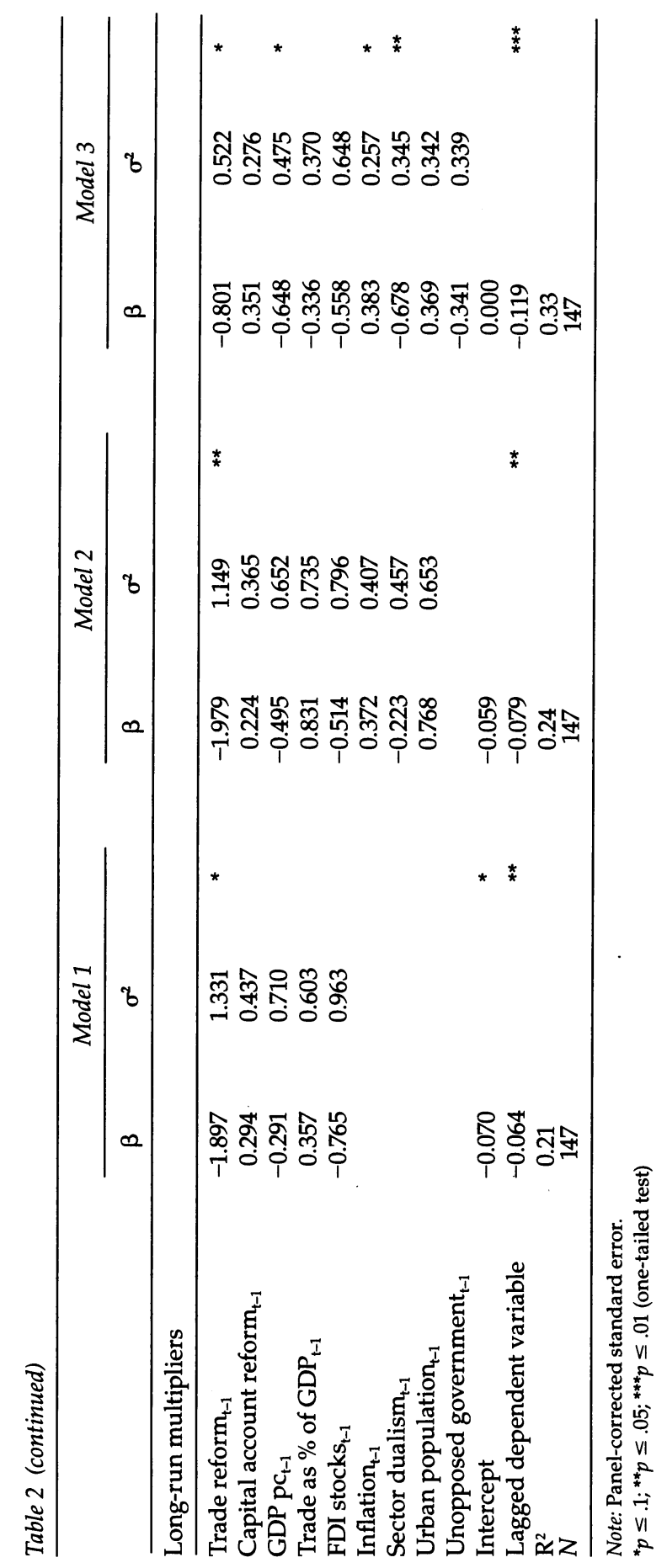




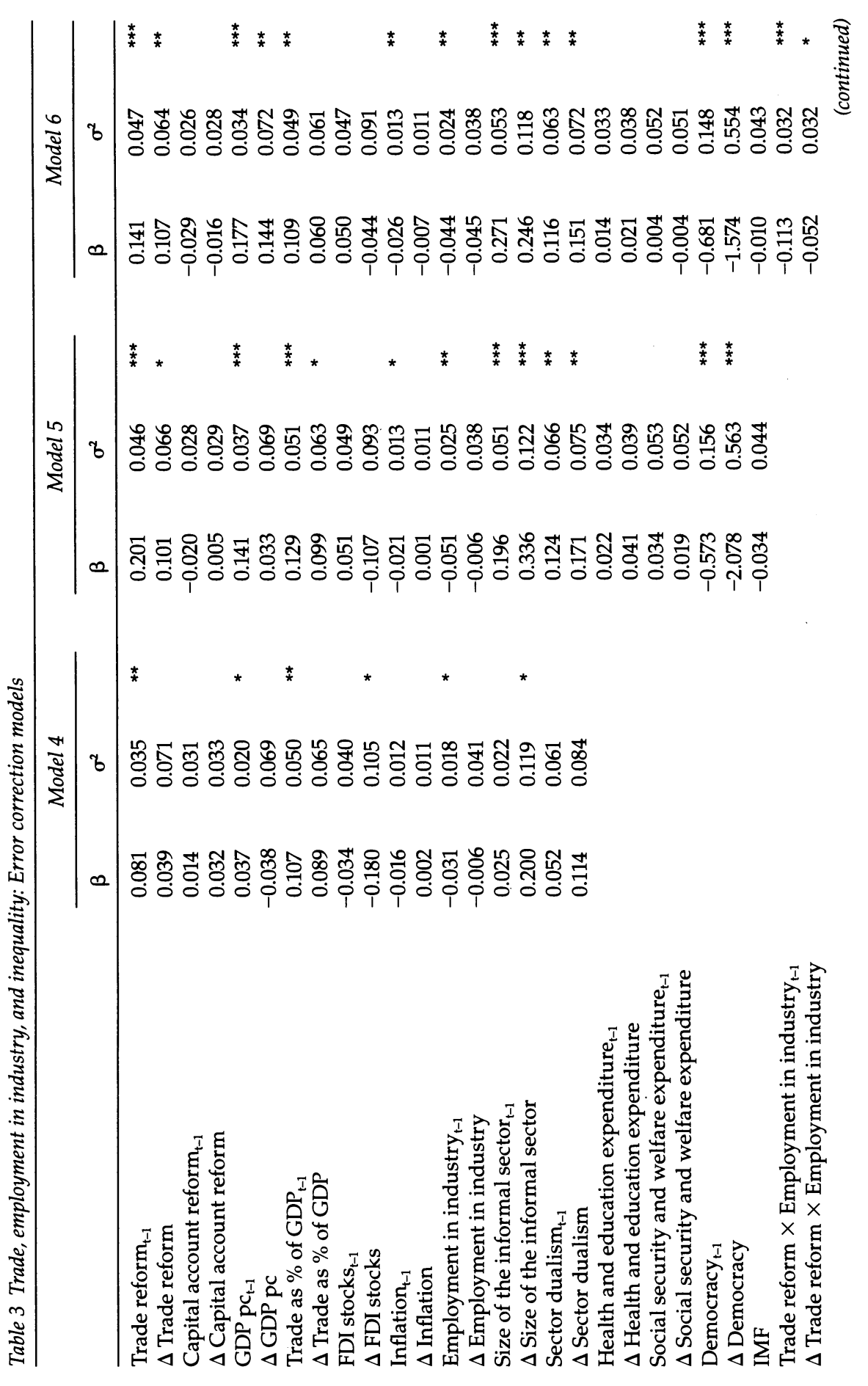




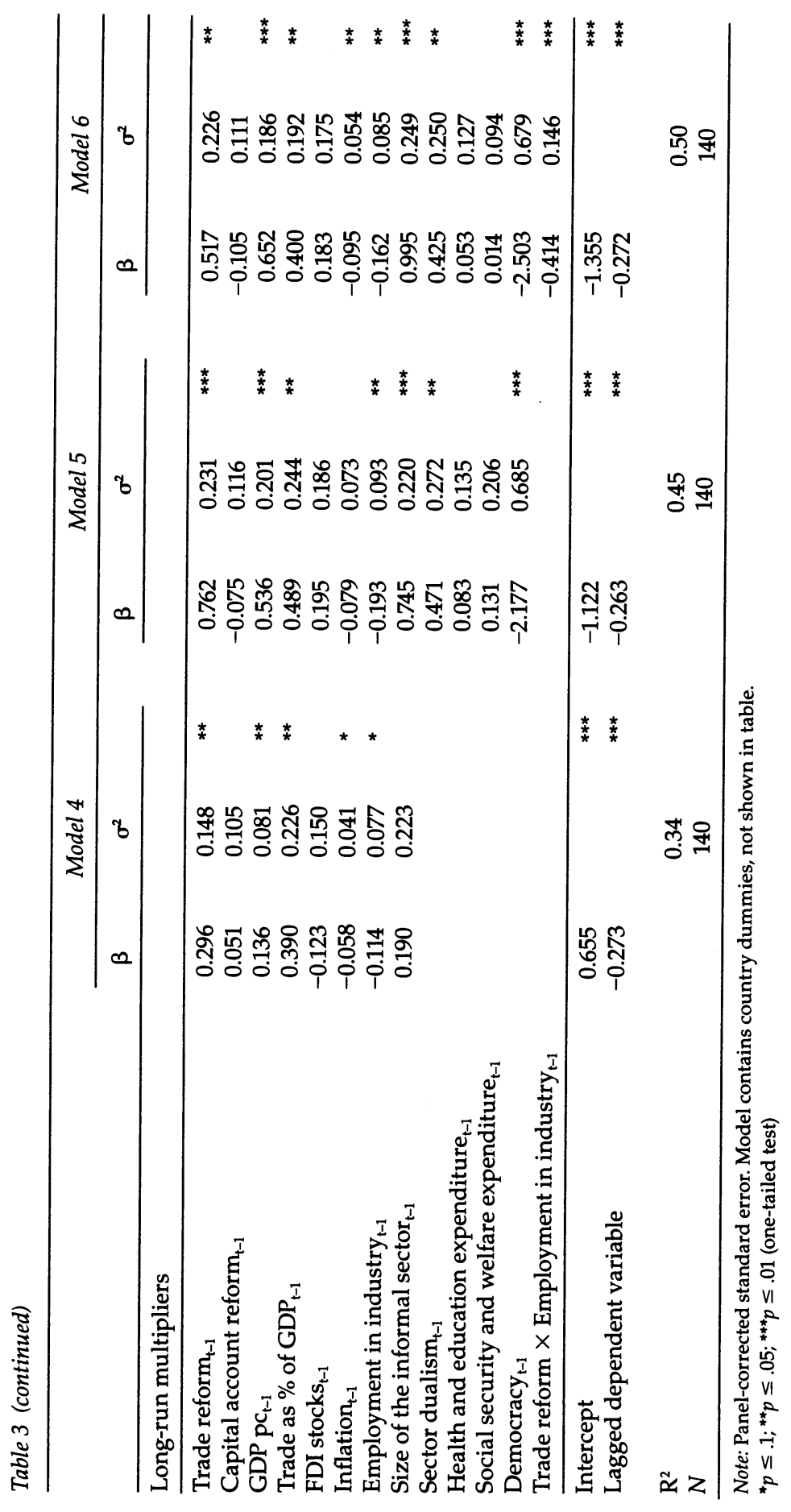




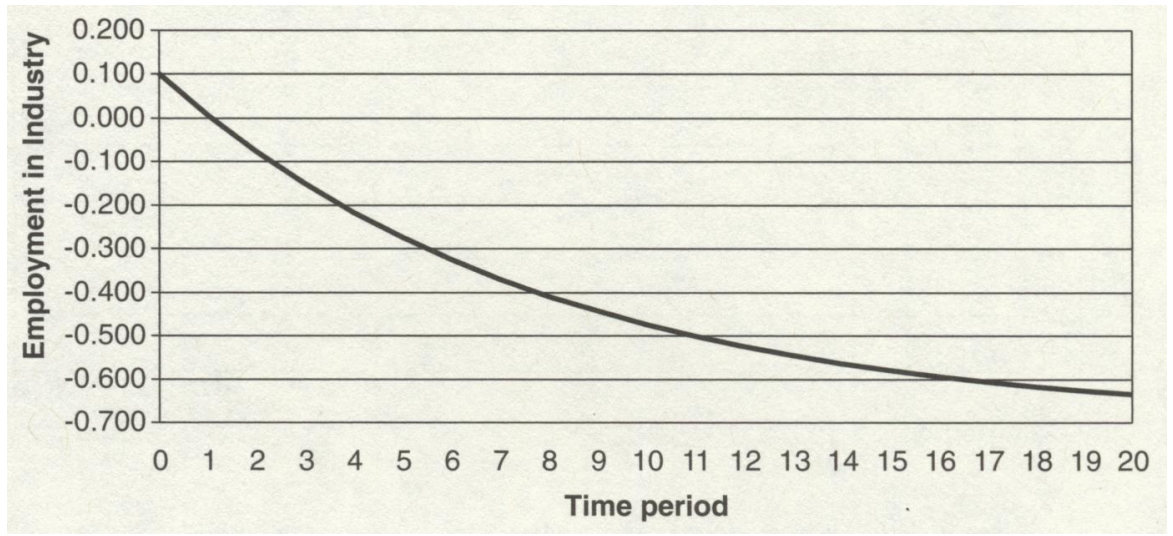

Figure 3 Long-term effect of trade reform on employment in industry.

cally significant and inversely related to employment in industry, which suggests that membership in Mercosur is significantly associated with the destruction of industrial employment. On the contrary, for the analyzed period, membership in NAFTA is significantly associated with industrial employment generation, which is consistent with the evidence from studies analyzing the short-term effect of the maquila industry in Mexico (Jensen and Rosas 2007).

The other three predictors with statistically significant long-term effects on employment in industry are GDP per capita, inflation, and sector dualism. GDP per capita has a significant negative effect on employment in industry. This is consistent with Brady, Kaya, and Gereffi's (2011) findings and suggests that, in the context of strong liberalization of the economy, increasing worker productivity has a significant negative effect on industrial employment. The effect of inflation on employment in industry is statistically significant. As the hyperinflation was curved during the first half of the 1990s, the destruction of employment in industry intensified. The fact that the sign of the relationship is positive has to do with this simultaneous drop in both variables. Finally, higher values of sector dualism, indicating the coexistence of a low-productivity traditional sector and a high-productivity modern sector, are associated with higher levels of employment in industry destruction. This is consistent with a trade liberalization pattern that benefited exporters of primary products over those of manufacturing products.

\section{Employment in Industry and Inequality}

Having unveiled the association between trade liberalization and employment in industry, the second stage of the analysis consists of assessing the relationship between the deindustrialization process and income inequality. Models 4 and 5 suggest that there is a statistically significant effect of employment in industry on inequality. The sign of the effect is negative, which suggests that destruction of this kind of employment is associated with an increase in inequality. Model 6 


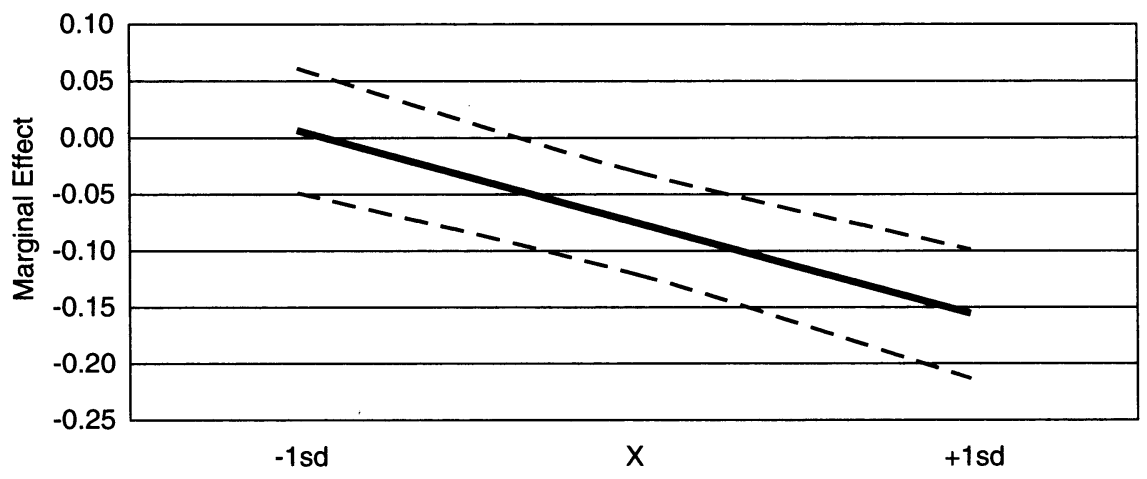

Figure 4 Marginal effect of employment in industry on inequality for different levels of trade reform.

refines the analysis by adding an interaction term between trade liberalization and employment in industry to test the hypothesis about the moderating effect of trade liberalization on the relationship between the other two phenomena. The interaction term belongs to the model.

Model 6 shows that the destruction of formal employment in the industrial sector is significantly associated with increased inequality in the long run. The model shows that the destruction of formal employment in the industrial sector was detrimental to equality. As expected, the interaction term suggests that the long-term effects of trade liberalization and level of employment in industry on inequality are not independent of one another..$^{17}$ As trade liberalization advanced, formal employment in industry shrank and its negative long-term effect on inequality increased. Figure 4 shows how the marginal effect of employment in industry on inequality becomes stronger and statistically significant as trade liberalization advances.

Therefore, the association between employment in industry and inequality becomes significant only as trade reform advances. Figure 5 shows the longterm effect of employment in industry on inequality when trade reform is at its mean, one standard deviation below its mean, and one standard deviation above its mean. This suggests that the long-term effect of employment in industry on inequality is almost inexistent when trade reform is at one standard deviation below its mean.

The long-term effect of employment in industry on inequality when trade liberalization is at its mean is statistically significant $(p \leq .001)$. A decrease in employment in industry will cause deviations from these two variables' equilibrium, thus causing inequality to be too low. In the short term, inequality will increase by 0.52 points per each unit decrease in employment in industry. This short-term relationship is also statistically significant. Therefore, inequality will

17. For detailed explanation on calculation of interaction terms, in particular among continuous variables, see Brambor, Clark, and Golder (2005). 


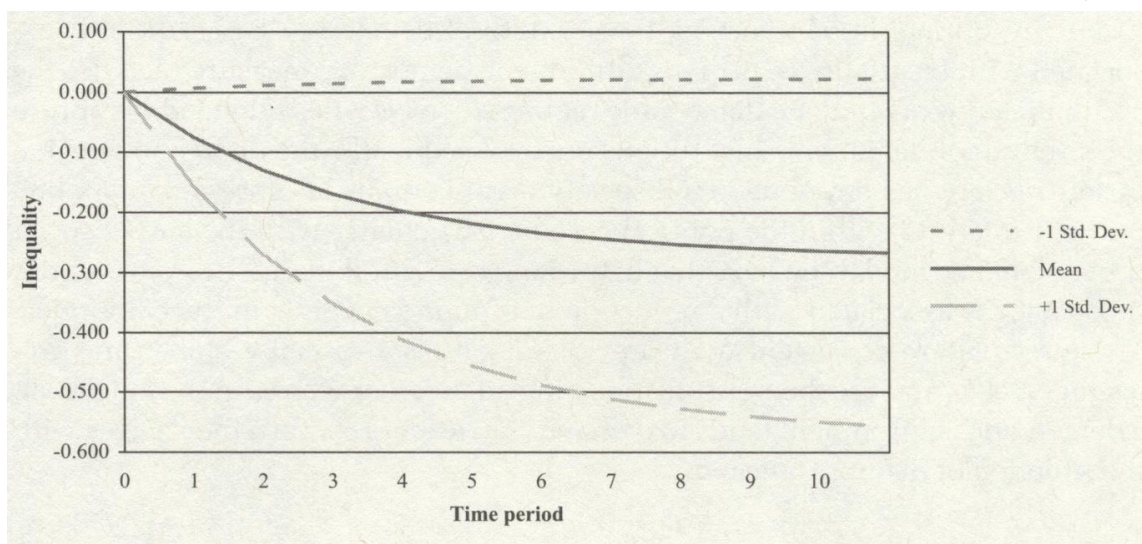

Figure 5 Long-term effect of employment in industry on inequality for different levels of trade reform.

respond in the long run by decreasing by a total of 0.276 points, spread over future time periods at a rate of 27 percent per time period (see figure 5).

When trade liberalization is at one standard deviation above its mean, the relationship between employment in industry and inequality becomes stronger. It remains statistically significant $(p \leq .001)$. At this level of trade reform, a unit decrease in employment in industry will cause inequality to respond in the long run by decreasing by a total of 0.574 points, spread over future time periods at a rate of 27 percent per time period (see figure 5).

Consistent with these findings, the increase in the size of the informal sector of the economy is significantly associated in the long run with increased inequality. For the seven analyzed countries and with influence of the other variables held constant, a unit increase in employment in the informal sector as a share of total employment is associated with a 0.99-point increase in the Gini index over the long term. These results support the hypothesis that a change in inequality is associated with changes in the structure of the labor market, through the deindustrialization process during the period.

Increases in GDP per capita are significantly associated in the long run with increases in inequality. This result is consistent with Kuznets's (1955) postulation about the implausibility of developing economies being able to curve inequality as the advanced industrial democracies did. Increases in trade are also statistically significantly associated with increases in inequality in the long run, which is consistent with the overall picture exposed in the analysis. Reduced inflation (and hyperinflation) over the period is associated with an increase in inequality in the long run, which suggests that the reduction of the comparative advantages that come from being a cheaper producer may have an effect on inequality as well. Finally, the long-term significant effect of sector dualism on inequality is consistent with the results in model 3 , as well as with the hypothesis on the particular harm of trade liberalization on those economies in the region that had further industrialized under the ISI model. 


\section{Latin American Research Review}

Finally, but not less important, the strength of democracy is significantly associated with inequality in the long run. As the democracy measure includes the accumulated years under a democratic regime since 1945, it is intended to capture the strength of democratic institutions and, consequently, the degree to which a certain society has developed civil society organizations to represent and lobby for their interests within the political system, particularly with the aim of social protection. The model suggests that in the long run, a unit increase in years under democracy is associated with a reduction of around 2.5 points in the Gini index. These results are consistent with previous analyses, especially Huber and colleagues (2006), and are theoretically meaningful. In other words, in the long term, a democratic environment tends to demand that leaders concern themselves with the situation of the unprivileged.

\section{CONCLUSION}

This analysis aimed to shed light on the contested debate about the causal association between trade liberalization and income inequality. The results suggest that such a causal connection existed for the countries and period analyzed, and they unveil the mechanism of deindustrialization as the causal link between the two phenomena.

The analysis supports an overall negative picture of the effect of reforms toward trade liberalization on income inequality. In other words, trade reform had a clear detrimental effect on equality through its fostering of deindustrialization. However, trade liberalization was a necessary step to integrate domestic economies into the global markets, and its effects were partly due to the implementation strategy, which responded to the type of capitalism that reformist governments and IFIs attempted to build: the reforms were sudden and lacked necessary accompanying increases in welfare safety nets.

Increases in inequality are better contained in democracies than in authoritarian regimes. The results of this analysis undoubtedly support the theoretical claim regarding the importance of democracy in shaping the distribution of welfare. In the case of Latin America, a history of democracy matters for explaining the elite's incentives for redistribution. Over the long term, because the existence of democratic institutions predicts social integration, the longer the record of democracy in a country, the stronger social institutions other than the state tend to be and the more costly it is for politicians to engage in welfare-retrenching policies.

Overall, the emphasis of the neoliberal model on principles of efficiency and market competition over welfare spending and social protection was a politically designed strategy. The worsening of the region's already-skewed income distribution during the liberal reform years resulted from political decisions concerning specific policy options and the specific model of capitalism that proponents of liberalization favored. In particular, the Latin American version of this model failed to formulate an alternative welfare structure for coping with the two most important and predictable social consequences of its reforms: the deindustrialization process and the consequential growth of the informal sector of the economy. 
While it is hardly debated that the ISI model had to be ousted, the form in which the political economies analyzed here transitioned into the global market reminds one of Polanyi's or even Kuznets's assessments about the perils of topdown structural changes in highly unequal societies without strong democratic institutions. This study and its implications for the study of policies and political economies raise several questions for future research. Two questions are of particular interest. First, the region has grown in political and economic autonomy in the post-neoliberal period, while transforming itself into a regional economic center. Does regional integration then open a door to a regional product specialization in the manufacturing sector, with Brazil and its growing African market as the main consumers? Second, is the region as such politically capable of managing a process of sustainable reindustrialization? This question should be addressed from the perspectives of domestic politics and the regional integration process.

\section{APPENDIX}

Table A1 Fisher test with augmented Dickey-Fuller test (three lags)

\begin{tabular}{lcc}
\hline & $\chi^{2}(14)$ & Prob. $>\chi^{2}$ \\
\hline Gini index & 15.466 & 0.491 \\
Trade reform & 43.226 & 0.000 \\
Capital account reform & 13.299 & 0.503 \\
GDP per capita & 10.617 & 0.716 \\
Trade as \% of GDP & 6.603 & 0.949 \\
FDI stocks & 0.778 & 1.000 \\
Inflation & 15.084 & 0.372 \\
Size of the informal sector & 11.670 & 0.766 \\
Sector dualism & 15.084 & 0.782 \\
Employment in industry & 10.008 & 0.762 \\
Urban population & 14.898 & 0.385 \\
Health and education expenditure & 18.982 & 0.166 \\
Social security and welfare expenditure & 9.452 & 0.801 \\
Unopposed regime & 4.869 & 0.988 \\
Democracy & 0.744 & 1.000 \\
\hline
\end{tabular}

Note: The Fisher test combines the $p$ values from $N$ independent unit root tests, as developed by Maddala and $\mathrm{Wu}$ (1999). Based on the $p$ values for individual unit root tests, Fisher's test assumes that all series are nonstationary under the null hypothesis against the alternative that at least one series in the panel is stationary. 


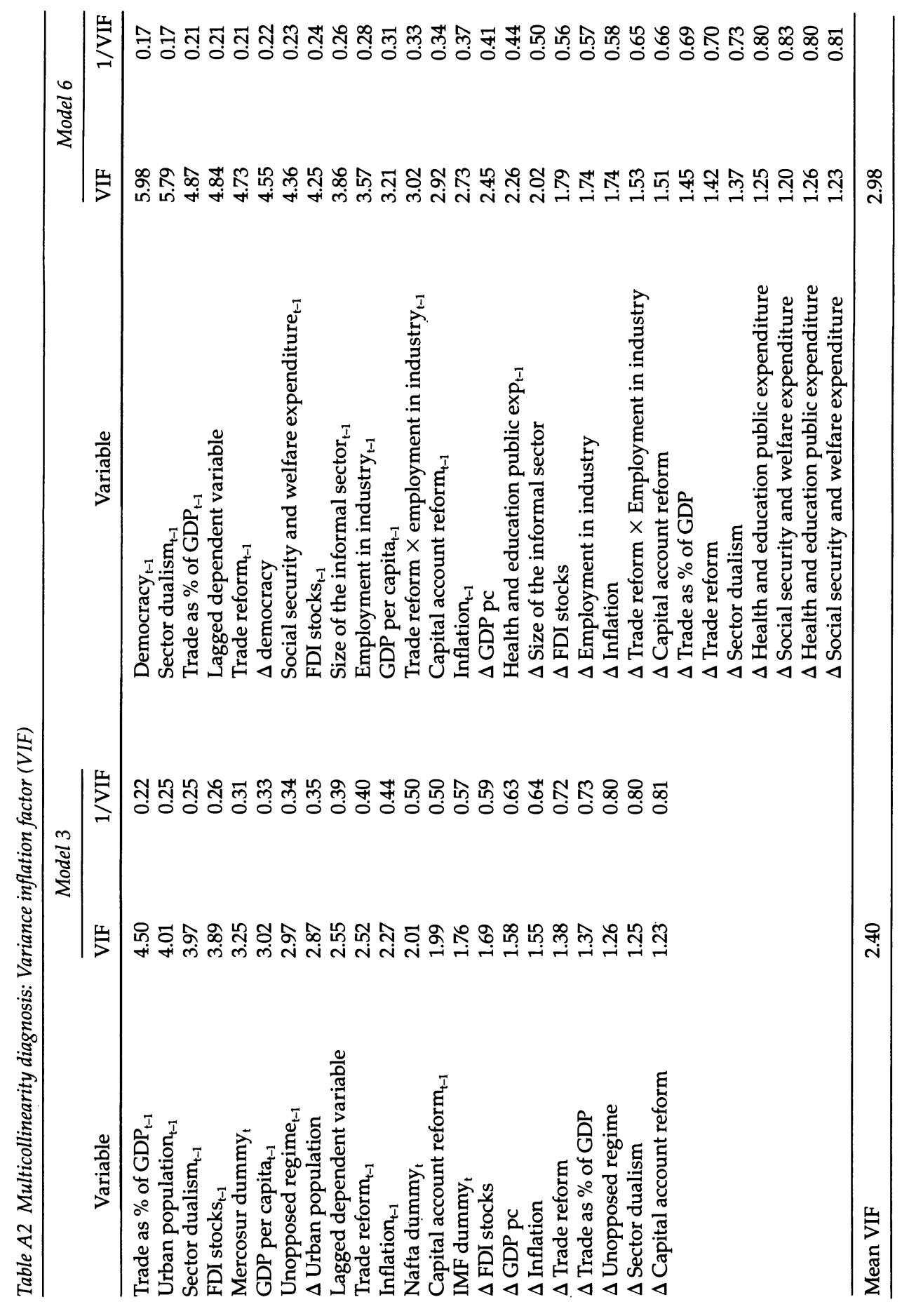


Table A3 Heteroskedasticity diagnosis: Breusch-Pagan/Cook-Weisberg test

\begin{tabular}{lcc} 
& $\chi^{2}(1)$ & Prob. $>\chi^{2}$ \\
\hline Model 3 & 1.680 & 0.195 \\
Model 6 & 1.890 & 0.169 \\
\hline $\mathrm{H}_{0}$ : Constant variance & &
\end{tabular}

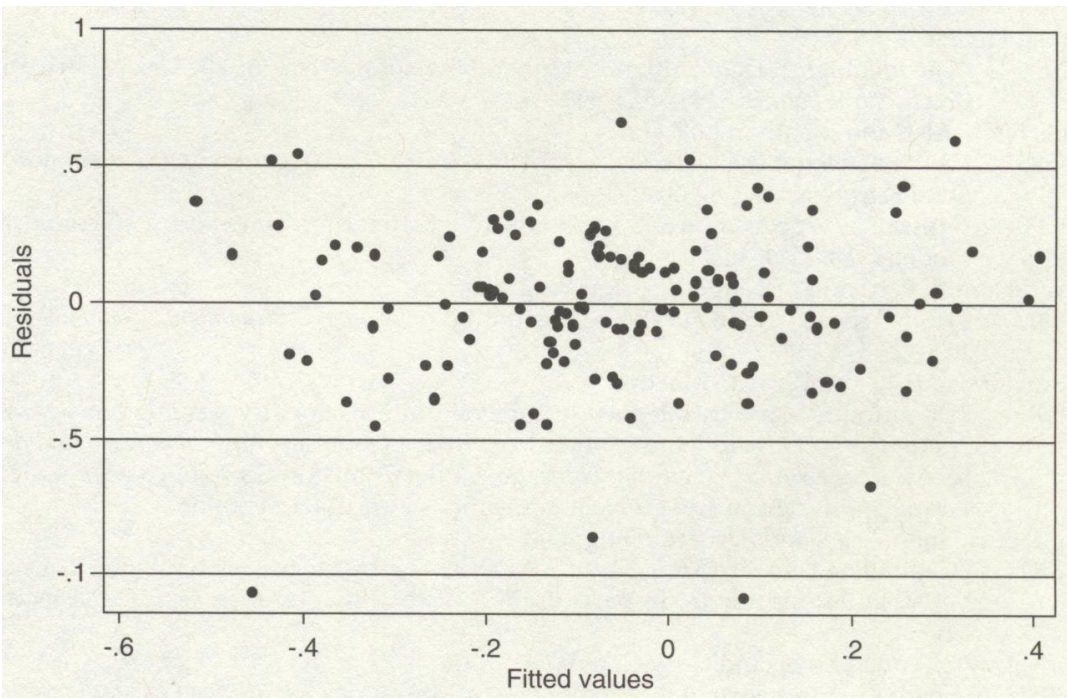

Figure A1 Stage 1 models: Fitted values versus residuals.

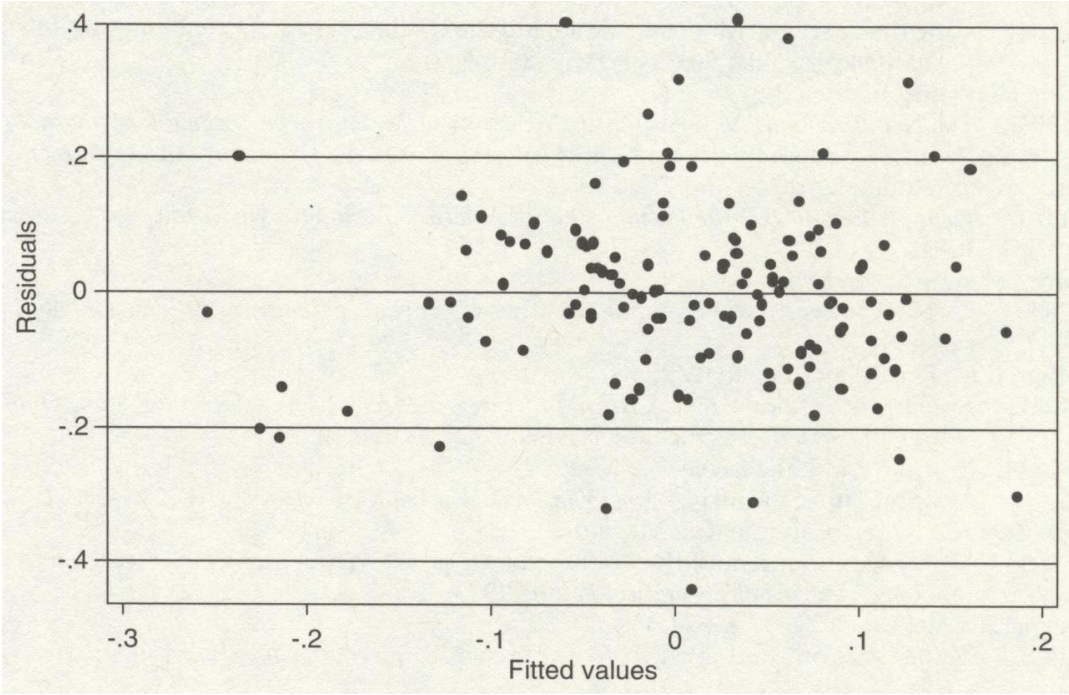

Figure A2 Stage 2 models: Fitted values versus residuals. 


\section{REFERENCES}

Aedo, C., ạnd L. Lagos

1984 “Protección efectiva en Chile, 1974-1979." Documento de Trabajo No. 94, Instituto de Economía, Universidad Católica de Chile, Santiago.

Alderson, Arthur S., and François Nielsen

1999 "Income Inequality, Development, and Dependence: A Reconsideration." American Sociological Review 64 (4):.606-631.

Appel, Hilary

2000 "The Ideological Determinants of Liberal Economic Reform: The Case of Privatization." World Politics 52 (4): 520-549.

Beck, Nathaniel, and Jonathan N. Katz

1995 "What To Do (and Not To Do) with Time-Series Cross-Section Data." American Political Science Review 89 (3): 634-647.

1996 "Nuisance vs. Substance: Specifying and Estimating Time-Series Cross-Section Models." Political Analysis 6 (July): 1-37.

Beyer, Harald, Patricio Rojas, and Rodrigo Vergara

1999 "Trade Liberalization and Wage Inequality." Journal of Development Economics 59 (1): 103-123.

Bhagwati, Jagdish, and Ricardo Martin

1980 "Un enfoque sobre estrategias de comercio internacional y sus incidencias sobre el empleo y el crecimiento económico." In ¿Se puede superar la pobreza? Realidad y perspectivas en América Latina. Santiago, Chile: Comisión Económica para América Latina and Programa de las Naciones Unidas para el Desarrollo.

Bogliaccini, Juan Ariel, and Fernando Filgueira

2011 "Capitalismo en el Cono Sur de América Latin luego del final del Consenso de Washington: ¿notas sin partitura?" Revista del CLAD Reforme y Democracia 51: 24-56.

Brady, David, Yunus Kaya, and Gary Gereffi

2011 "Stagnating Industrial Employment in Latin America." Work and Occupations 38 (2): 179-220.

Brambor, Thomas, William Roberts Clark, and Matt Golder

2005 "Understanding Interaction Models: Improving Empirical Analyses." Political Analysis 14 (1): 63-82.

Brune, Nancy, Geoffrey Garrett, and Bruce Kogut

2004 "The International Monetary Fund and the Global Spread of Privatization." International Monetary Fund Staff Papers 51 (2): 195-219.

Bulmer-Thomas, Victor, ed.

1996 The New Economic Model in Latin America and Its Impact on Income Distribution and Poverty. London: Institute of Latin American Studies, University of London.

Cardoso, Fernando Henrique, and Enzo Faletto

1979 Dependency and Development in Latin America. Berkeley: University of California Press.

Chinn, Menzie D., and Hiro Ito

2008 "A New Measure of Financial Openness." Journal of Comparative Policy Analysis 10 (3): 309-322.

Collier, Ruth Berins, and David Collier

1991 Shaping the Political Arena: Critical Junctures, the Labor Movement, and Regime Dynamics in Latin America. Princeton, NJ: Princeton University Press.

De Boef, Suzanna, and Luke Keele

2008 "Taking Time Seriously." American Journal of Political Science 52 (1): 184-200.

Díaz-Cayeros, Alberto, and Beatriz Magaloni

2001 "Party Dominance and the Logic of Electoral Design in Mexico's Transition to Democracy." Journal of Theoretical Politics 13 (3): 271-293.

Drezner, Daniel W.

2001 "Globalization and Policy Convergence." International Studies Review 3 (1): 53-78. 
2007 All Politics Is Global: Explaining International Regulatory Regimes. Princeton, NJ: Princeton University Press.

ECLAC (Economic Commission for Latin America and the Caribbean)

1993 Social Panorama of Latin America. Santiago, Chile: ECLAC.

2010 Social Panorama of Latin America. Santiago, Chile: ECLAC.

Enders, Walter

2004 Applied Econometric Time Series. Hoboken, NJ: Wiley.

Escaith, Hubert, and Igor Paunovic

2004 "Reformas estructurales en América Latina y el Caribe en el periodo 1970-2000." ECLAC. http://ssrn.com/abstract $=1158491$.

Esping-Andersen, Gøsta

1990 The Three Worlds of Welfare Capitalism. Cambridge: Polity Press.

Feenstra, Robert C., and Gordon H. Hanson

1997 "Foreign Direct Investment and Relative Wages: Evidence from Mexico's Maquiladoras." Journal of International Economics 42 (3): 371-393.

Filgueira, Carlos H., and Fernando Filgueira

2002 "Models of Welfare and Models of Capitalism: The Limits of Transferability." In Models of Capitalism: Lessons for Latin America, edited by Evelyne Huber, 127-158. University Park: Pennsylvania State University Press.

Filgueira, Fernando, and Juan Ariel Bogliaccini

2004 "Las reformas educacionales en Chile y Uruguay: Descentralización orientada al mercado versus centralismo estatista." In Descentralización y políticas sociales en América Latina, edited by Ricard Gomà and Jacint Jordana, 297-348. Barcelona: Centre d'Estudis i Documentació Internacionals (CIDOB).

Gatica Barros, Jaime

1989 Deindustrialization in Chile. Boulder, CO: Westview Press.

Goldthorpe, John H., ed.

1984 Order and Conflict in Contemporary Capitalism. Oxford, UK: Clarendon Press.

Hanson, Gordon H., and Ann Harrison

1999 "Trade Liberalization and Wage Inequality in Mexico." Industrial and Labor Relations Review 52 (2): 271-288.

Harvey, David

2005 A Brief History of Neoliberalism. New York: Oxford University Press.

Heston, Alan, Robert Summers, and Bettina Aten

2009 Penn World Table Version 6.3. Center for International Comparisons of Production, Income and Prices at the University of Pennsylvania, August.

Honaker, James, and Gary King

2007 "What to Do about Missing Values in Time Series Cross-Section Data." http://gking .harvard.edu/files/pr.pdf.

Huber, Evelyne

1996 "Options for Social Policy in Latin America: Neoliberal versus Social Democratic Models." In Welfare States in Transition: National Adaptations in Global Economies, edited by Gøsta Esping-Andersen, 141-191. London: Sage.

2002 Models of Capitalism: Lessons for Latin America. University Park: Pennsylvania State University Press.

Huber, Evelyne, François Nielsen, Jenny Pribble, and John D. Stephens

2006 "Politics and Inequality in Latin America and the Caribbean." American Sociological Review 71 (December): 943-963.

Huber, Evelyne, and John D. Stephens

2001 Development and Crisis of the Welfare State: Parties and Policies in Global Markets. Chicago: University of Chicago Press.

ILO (International Labor Organization)

1998 Labor Panorama. Geneva: ILO.

2010 Online Database on Labor Statistics (LABORSTA). http://laborsta.ilo.org.

IMF (International Monetary Fund)

2010a Government Finance Statistics Yearbook. New York: IMF.

2010b International Financial Statistics Yearbook. New York: IMF. 


\section{Latin American Research Review}

Iversen, Torben

2005 Capitalism, Democracy, and Welfare. New York: Cambridge University Press.

Jensen, Nathan M., and Guillermo Rosas

2007 "Foreign Direct Investment and Income Inequality in Mexico, 1990-2000." International Organization 61 (2): 467-487.

Kaufman, Robert R., and Alex Segura-Ubiergo

2001 "Globalization, Domestic Politics, and Social Spending in Latin America: A TimeSeries Cross-Section Analysis, 1973-97." World Politics 53 (4): 553-587.

Keohane, Robert

1984 "The World Political Economy and the Crisis of Embedded Liberalism." In Order and Conflict in Contemporary Capitalism, edited by John H. Goldthorpe, 15-38. Oxford, UK: Clarendon Press.

Kuznets, Simon

1955 "Economic Growth and Income Inequality." American Economic Review 45 (1): $1-28$.

Maddala, G. S., and Shaowen Wu

1999 "A Comparative Study of Unit Root Tests with Panel Data and a New Simple Test." Oxford Bulletin of Economics and Statistics 61 (S1): 631-652.

Madrid, Raúl L.

2005 "Ideas, Economic Pressures, and Pension Privatization." Latin American Politics and Society 47 (2): 23-50.

Marjit, Sugata, and Rajat Acharyya

2003 International Trade, Wage Inequality and the Developing Economy: A General Equilibrium Approach. New York: Physica-Verlag.

Marjit, Sugata, Hamid Beladi, and Avik Chakrabarti

2004 "Trade and Wage Inequality in Developing Countries." Economic Inquiry 42 (2): 295-303.

Morley, Samuel A.

2001 The Income Distribution Problem in Latin America and the Caribbean. Santiago, Chile: United Nations Press.

Morley, Samuel A., Roberto Machado, and Stefano Pettinato

1998 Indexes of Structural Reform in Latin America. Reformas Económicas No. 12. Santiago, Chile: United Nations Press.

Mosley, Layna, and Saika Uno

2007 "Racing to the Bottom or Climbing to the Top? Economic Globalization and Collective Labor Rights." Comparative Political Studies 40 (8): 923-948.

Polanyi, Karl

1944 The Great Transformation. Boston: Beacon Press.

Pontusson, Jonas

2005 Inequality and Prosperity: Social Europe vs. Liberal America. Ithaca, NY: Cornell University Press.

Portes, Alejandro, and Kelly Hoffman

2003 "Latin American Class Structures: Their Composition and Change during the Neoliberal Era." Latin American Research Review 38 (1): 41-82.

Portes, Alejandro, and Bryan R. Roberts

2005 "The Free-Market City: Latin American Urbanization in the Years of the Neoliberal

Prebisch, Raúl Experiment." Studies in Comparative Institutional Development 40 (1): 43-82.

1952 Problemas teóricos y prácticos del crecimiento económico. Santiago, Chile: Comisión Económica para América Latina y el Caribe. Reprinted in Cincuenta años de pensamiento de la CEPAL, vol. 1. Santiago, Chile: ECLAC and Fundación de Cultura Económica, 1998.

Rueschemeyer, Dietrich, Evelyne Huber Stephens, and John D. Stephens

1992 Capitalist Development and Democracy. Chicago: University of Chicago Press.

Schneider, Ben Ross, and David Soskice

2009 "Inequality in Developed Countries and Latin America: Coordinated, Liberal and Hierarchical Systems." Economy and Society 38 (1): 17-52. 
Segura-Ubiergo, Alex

2007 The Political Economy of the Welfare State in Latin America: Globalization, Democracy, and Development. New York: Cambridge University Press.

Solt, Frederick

2009 "Standardizing the World Income Inequality Database." Social Science Quarterly 90 (2): 231-242.

Spilimbergo, Antonio, Juan Luis Londoño, and Miguel Székely

1999 "Income Distribution, Factor Endowments, and Trade Openness." Journal of Development Economics 59 (1): 77-101.

UN Conference on Trade and Development

2009 Online Statistics Database. http://unctad.org/en/Pages/Statistics.aspx.

United Nations Development Program

1995 Human Development Report. New York: UN Development Program.

Welsch, Roy E., and Edwin Kuh

1977 "Linear Regression Diagnostics." Working Paper No. 173, March 1977, National Bureau of Economic Research, Cambridge, MA.

Wibbels, Erik

2006 "Dependency Revisited: International Markets, Business Cycles, and Social Spending in the Developing World." International Organization 60 (2): 433-468.

Williamson, Oliver E.

1985 The Economic Institutions of Capitalism: Firms, Markets, Relational Contracting. New York: Free Press.

Woods, Adrian

1997 "Openness and Wage Inequality in Developing Countries: The Latin American Challenge to East Asian Conventional Wisdom." World Bank Economic Review 11 (1): 33-57.

World Bank

2011 "World Development Indicators." http://www.worldbank.org/data.

World Institute for Development Economics Research

2008 World Income Inequality database. World Institute for Development Economics Research, United Nations University. http://www.wider.unu.edu. 